\title{
Students' Perspective of Google Classroom (GCR) Online Learning during Covid-19 Pandemic
}

\author{
Novalia Rani Jayatri \\ IAIN Bengkulu \\ novaliaranijayatri@gmail.com \\ Risnawati \\ IAIN Bengkulu \\ risnawati@iainbengkulu.ac.id \\ Ferri Susanto \\ IAIN Bengkulu \\ Ferialfa02@gmail.com
}

\begin{abstract}
This research aimed to find out the implementation of Google Classroom (GCR) in Online Learning during Covid-19 Pandemic for the second year students of SMAN 08 Kota Bengkulu and to find out the Students' Perspective of Google Classroom (GCR) in Online Learning during Covid-19 Pandemic at SMAN 08 Kota Bengkulu. There were 30 students who participated in this research gathered by using purposive sampling. The research method applied in this current study was a qualitative method. The data were collected through observation, interviews and documentation. To analyze the data, the researcher applied the theory from Miles and Huberman (1994). The result of the first research question showed that Google Classroom was used frequently by the teacher and students to conduct online learning. The result of the second research question demonstrated that only $48,84 \%$ of the students were satisfied with the use of Google Classroom. The students were not satisfied the most with the students' indicator of satisfaction, which reached $75 \%$. However, $92,7 \%$ of them gave positive feedback towards the instruction delivery. Overall, this result suggested that Google Classroom did not received positive feedback from the majority of the students, with some exception of instruction delivery. The researcher recommended the teacher at SMAN 08 Kota Bengkulu to provide more creative way in online teaching, so students have the opportunity to learn more effectively.
\end{abstract}

Keyword: Google Classroom, Online Learning, Student perspectives.

\section{A. Introduction}

The Covid 19 pandemic has created many changes to almost all aspects, including education. The Minister of Education and Culture has issued a policy Number 36962 / MPK.A / HK / 2020 which decided that schools should conduct online Learning and people must work from home as an attempt to reduce the risk and prevent the Spread of the pandemic. (Arora AK, 2020). Therefore, the system of learning experienced changes to online system, compared to offline system. One method to support distance learning is Google classroom, This is a free web service developed by Google that aims at face-to-face, 
distance learning process that combines Google Drive for assignment creation and submission, Google Docs, Sheets, and Slides for writing, Gmail for communication, and Google Calendar for scheduling (Nagele, 2017).

Both teachers and students must have a broad knowledge of how to apply Google Classroom In online learning during the pandemic, and of course students' perspectives arise, it can be understood that what is meant by perspective is where something is viewed from a certain point of view to be known or to know something to be observed. In academic life, Google Classroom has several features that are applicable in academic life.

Some studies have been conducted to seek for answers about the students's perspectives in using the tool. The first previous study was conducted by Marsika Sepyanda (2018). The purpose of this research was to to know the students' attitude toward the use of Google Classroom as an application used in collecting their assignment on Translation subject. The result of this study found that students' attitude toward the use of Google Classroom in collecting their assignment on Translation subject was in the "good" level. The other researcher focused on the teachers' perception towards the use of Google Classroom. Azhar (2018), revealed that teachers applied Google Classroom as document management and basic classroom management, without having a great influence on the methodologies of teaching. The responses given by the teachers demonstrated that the utimate reason of ineffiency was the lack in user-friendly interface.

Since March 2020, since the government has urged all schools and colleges not to do face-to-face learning, SMAN 8 Kota Bengkulu is one of the schools that has used elearning as a learning medium where e-Learning learning activities at the school take advantage of google classroom. here have different perceptions about distance learning because distance learning is considered there is what is expected and some is not what is expected. Based on interviews conducted on February 25, 2021, there were several obstacles in using Google Classroom (GCR), namely: Network (unstable internet connection), SMAN 8 students have not fully mastered the use of GCR, Interaction between teachers and students is still lacking (students feel embarrassed to ask questions or comment to the teacher about lessons or difficulties experienced in doing assignments given in Google Classroom).

Based on the explanation above, the researcher conducted further research entitled: Student Perspectives in Google Classroom Online Learning (GCR) During the Covid-19 Pandemic (Qualitative Study in Grade 2 students of SMAN 08 Kota Bengkulu). 


\section{B. Research Methodology}

The research design applied in this research was descriptive qualitative research. Qualitative research was research that used methods such as participant observation or case studies that produce narrative, descriptive explanations about settings or practices (Parkinson, 2011). The subjects of the research were the 2nd year students of SMAN 08 Kota Bengkulu. The sample in this research is class XI IPS 1 which was consisted of 30 students. The participants in this research were collected using the purposive sampling. The purposive sampling technique, also called judgment sampling, is the deliberate choice of a participant due to the qualities the participant possesses.

The techniques of collecting data used in this research were observation, interview and documentation. Observation is one of the most important research methods in social sciences and at the same time one of the most diverse. The term includes several types, techniques, and approaches, which may be difcult to compare in terms of enactment and anticipated results; the choice must be adapted to the research problem and the scientifc context. This research applied semi-structured interview. Semi structured interviews are those in depth interviews where the respondents have to answer preset open ended questions and thus are widely employed by different healthcare professionals in their research.

There were 27 questions divided into 5 categories. They are accessibility, perceived usefulness, communication and interaction, perceived instruction delivery and students' satisfaction. The documentation in this study was carried out to obtain data relating to the form and use of Google Classroom on schools used in learning. Data obtained can be used to complement and perform comparison of data obtained from observations and interviews.

Analysis is the process of a researcher uses to reduce data top a story and its interpretation. (Schensul). Data analysis is the process of reducing large amount of collected data to make sense of them. Research data analysis is a process used by researchers for reducing data to a story and interpreting it to derive insights. The data analysis process helps in reducing a large chunk of data into smaller fragments, which makes sense. (LeCompte, 2010.) To analyze the data, four concurrent verification flow of activity in the model: data collection, data reduction, data display, and data conclusion drawing and verification (Huberman, 1994).

There are five steps in conducting the research: Locating and Defining Issues or Problems, Designing the Research Project, Collecting Data, Report Research Findings, Interpreting Research Data Report Research Findings (Dennis Howitt, 2000). In qualitative 
research, the research outcomes are measured to guarantee that they are credible, transferable, confirmable, and dependable. (James, 1979). There were various ways of ensuring the credibility of the research, such as Prolonged engagement, Persistent observation, and Triangulation. This research applied triangulation to make sure that the research is credible.

The type of triangulation applied in this research was methodological triangulation, using three different methods, namely: first, in-depth interviews, where students are asked several questions about the use of Google Classroom (GCR) in their learning, Second, observation, activities during class observation by observation or checklist. Third, field notes, in which specific or specific data from interviews and observations were used by the researcher.

\section{Results and Discussion}

\section{Results}

1. The implementation of online learning using Google Classroom during the time of Covid-19 Pandemic for the 2nd year students of SMAN 08 Kota Bengkulu.

\section{a. Observation}

Based on the observation, there were three activities in the classroom, which are devided into three parts: opening, core activities, closing.

\section{b. Opening}

In the opening, the teacher made observation towards the students' background knowledge by giving the students pre-test through Google Classroom and questions to evoke their knowledge. Then the teacher delivered the main goals of learning and explaining the process of learning.

\section{c. Core activities}

The teacher did the exploration activities by using learning media, one of which is Google Classroom. Besides, the teacher conducted elaboration activities by applying Google Classroom. After that, the teacher did a confirmation activities to students.

\section{d. Closing}

After all the activities have been carried out, the teacher closed the lesson and prayed together with the students. 
Table 4.1

Observation Guidelines

The learning process of Google Classroom during the Covid-19 pandemic

\begin{tabular}{|c|c|c|c|}
\hline No & Components & Sub Components & cheklist \\
\hline 1 & Opening & $\begin{array}{l}\text { a. Observing students' } \\
\text { background knowledge } \\
\text { b. Delivering the main goals } \\
\text { of learning and } \\
\text { explaining the process of } \\
\text { learning }\end{array}$ & \\
\hline 2 & Core activities & $\begin{array}{l}\text { a. Doing exploration } \\
\text { activities are carried out } \\
\text { by the teacher using } \\
\text { learning media } \\
\text { b. Conducting elaboration } \\
\text { activities by applying } \\
\text { google classroom } \\
\text { learning confirmation } \\
\text { c. Doing activities to students }\end{array}$ & \\
\hline 3 & Closing & $\begin{array}{l}\text { a. Closing the lesson and } \\
\text { praying }\end{array}$ & \\
\hline
\end{tabular}

2. The Students' Perspective of online learning using Google Classroom during the time of Covid-19 Pandemic of SMAN 08 Kota Bengkulu.

\section{a. Interview}

In this study, the researcher tried to find out students' perceptions about online learning using Google Classroom, as we know that the student's perspective was the ability of students to justify their own opinions about what they saw and felt. The results of this study were obtained by means of observation, as a form of data search and online interview techniques in the form of a Google Form which was shared through the Whatsapp group which then the researcher analyzed and documented obtained from the participant's Google Classroom account screenshot, the researcher took a sample of 30 class XI IPS 1 students. 


\section{Figure 4.1 The Result of Interview}

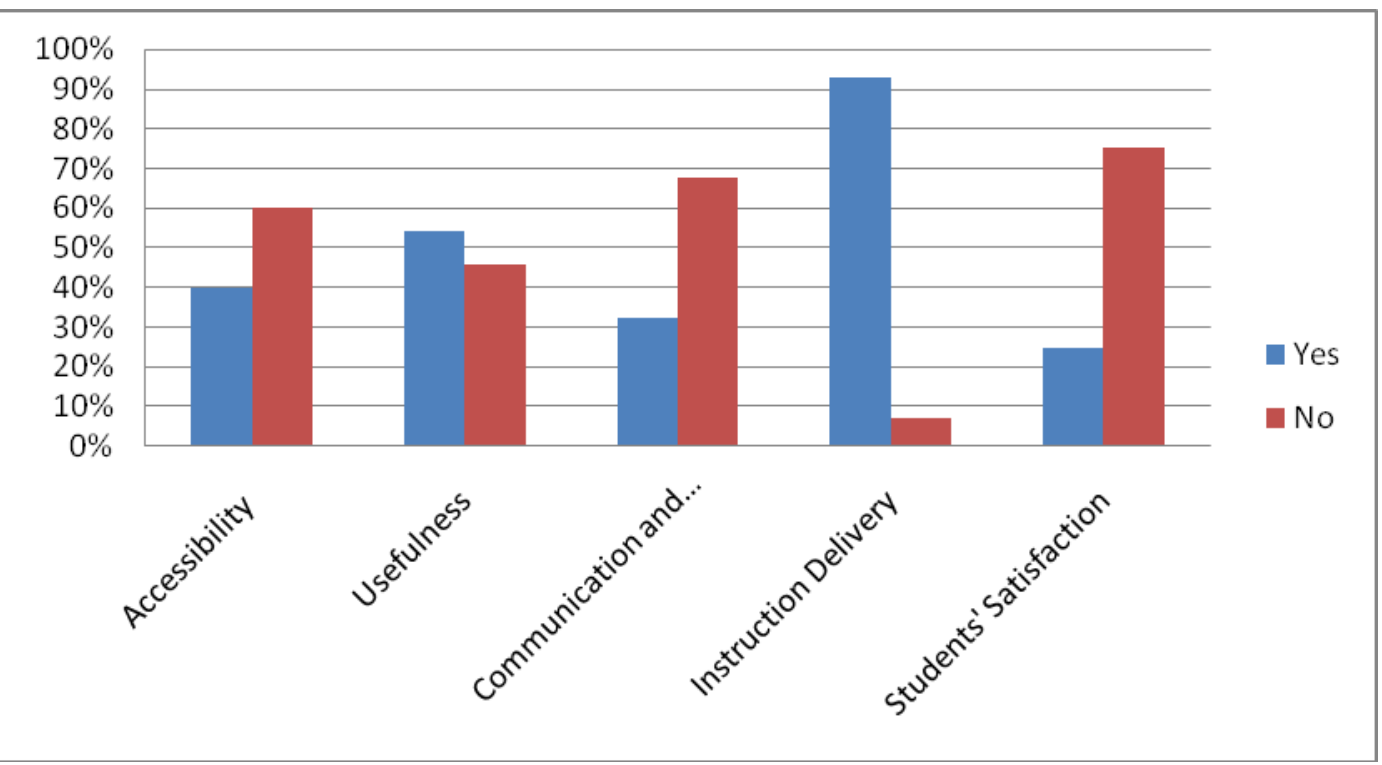

\section{Discussion}

The main objective of this research is about the implementation of Google Classroom Online Learning (GCR) during the Covid-19 Pandemic for 2nd grade students of SMAN 08 Bengkulu and the Google Classroom (GCR) Online Learning Student Perspective during the Covid-19 Pandemic for Grade 2 students of SMAN 08 Bengkulu. The researcher provides further interpretation and discussion as follows:

\section{The implementation of Google Classroom (GCR) Online Learning during Covid-19 Pandemic for the 2nd year students of SMAN 08 Kota Bengkulu.}

Based on the results of interviews that the researchers have described, the use of the google classroom application in online learning during the Covid-19 Pandemic at SMAN 8 Kota Bengkulu, was the policy of the school and the curriculum team on the grounds that it was easy to access and teachers had no difficulty in managing assignments, as well as being effective and efficient. However, some students said that the online learning process other than google classroom, the teacher used the WhatsApp, telegram, quipper, youtube application, even though they were still given the option to collect assignments manually or offline at school. Students say google classroom is a feature that is simple and easy to understand, it's just that they are not used to operating it. Students also said that the google 
classroom was only used to send assignments and were absent, even some teachers never held discussions in the google classroom.

The finding above is similar to the research outcome entitled: Students' Attitude Toward The Use of Google Classroom on Translation Subject In English Department Of Fkip Ummy Solok. It is concluded that the implementation of the google classroom application is very helpful for students in submitting their assignments, especially in translation subjects who usually carry weekly assignments.

Things that become more difficult focus on accessibility because the signal is from the student's residence, the absence of quotas, the large video capacity so that students have difficulty uploading or downloading assignments. Another problem that is felt is the boredom of students serving students while studying at home has an impact on feeling lazy to do. Even though learning has shifted to online learning, the material presented to students is in accordance with the Learning Implementation Plan (RPP). Changes are only in the methods and strategies applied to students.

From the findings, researchers can analyze that the process of implementing online learning during the Covid-19 Pandemic at SMAN 8 Kota Bengkulu, went according to school policy as a form of independent learning, namely learning carried out online. The process begins with instructing students to download the Google Classroom application on their respective laptops or gadgets. Even though the online learning process using the Google Classroom application has been running for about one year, the enthusiasm of the teachers and students is still carried out with great enthusiasm and motivation to always learn. This is in accordance with the answers of 30 students who are students at SMAN 8 Bengkulu who are competent and understand the Google Classroom application.

\section{The Students' Perspectives of Google Classroom (GCR) Online Learning during Covid-19 Pandemic of SMAN 08 Kota Bengkulu.}

From the results of online interviews that were distributed through the WhatsApp group in the form of google that were conducted by researchers on Students' Perspective of Google Classroom (GCR) Online Learning during Covid-19 Pandemic to class XI IPS 1 SMAN 8 Kota Bengkulu City. Overall, the result of the interview is as follow:

a. Accessibility

Regarding accessibility, $60 \%$ of students answered that Google Classroom is easy to access. While $40 \%$ of students believe that Google Classroom is still difficult to 
access, this shows that more than half of students answered that it is easy for them to access Google Classroom.

\section{b. $\quad$ Perceived Usefulness}

Regarding Perceived Usefulness, 54\% of students answered that the benefits felt by students from using google classroom learning became more organized, everything had been scheduled and in current conditions google classroom is considered appropriate as a medium for distance learning. Meanwhile $46 \%$ of students answered that google classroom has not fully provided benefits to students, this is due to the lack of student learning intention to care about papda, the assignments given by the teacher are too many, students are still comfortable learning directly.

\section{c. Communication and Interaction}

Regarding Communication and Interaction, 32.5\% of students answered that the interaction and communication between students and teachers and fellow students went well, more effectively, students were required to be more active in discussions. Meanwhile students answered that $67.5 \%$ of google classrooms were only used as a medium for teachers to send assignments, many teachers were difficult to contact when studying online.

\section{d. Preceived Instruction Delivery}

Related to preceive instruction delivery, $92.7 \%$ of students answered that the teacher had provided clear instructions on how to participate in learning activities, providing good feedback. Meanwhile, $7.3 \%$ of students answered no without giving any reasons.

\section{e. Students Satification}

Regarding Students Satification, $25 \%$ of students answered that students recommended this learning method to be applied to other appropriate subjects because the google classroom features were easy to understand. Meanwhile, $75 \%$ of students answered no, because Google classroom is only a medium for sending assignments and students still believe that offline classes are better than learning through Google Classrooms. 


\section{Conclusion and Suggestion}

\section{Conclusion}

There were five components of measurements to assess the students' perspective towards Google Classroom, they were accessibility, usefulness, communication and interaction, instruction delivery, and students' satisfaction. Overall, based on the result of the interview, there was less half of the total who demonstrated positive perspectives. Instruction delivery got the highest number of students who felt satisfied, followed by usefulness and accessibility.

However, usefulness and accessibility had greater percentage of students who did not feel satisfied. It was just about a quarter of the total students who demonstrated satisfaction towards the use of Google Classroom. For the accessibility, most of the students answered that it was easy to access Google Classroom since they had good signal, as those students live in the city, while for the usefulness, more than half of students answered that the benefits felt by students from using Google Classroom learning became more organized, everything had been scheduled and in current conditions google classroom is considered appropriate as a medium for distance learning.

For communication and interaction, only a small number of students answered that the interaction and communication between students and teachers and fellow students went well, more effectively, students were required to be more active in discussions, while the greater number of students believed that google classrooms were only used as a medium for teachers to send assignments, many teachers were difficult to contact when studying online.

For the perceived instruction delivery, almost of students answered that the teacher had provided clear instructions on how to participate in learning activities, providing good feedback, while for students' satisfaction, only a quarter of students answered that students recommended this learning method to be applied to other appropriate subjects because the Google Classroom features were easy to understand. 


\section{Suggestion}

Referring to this research result, I suggested for students who use Google Classroom in their online learning to maximize the use of Google Classroom as one of the learning tools. Students are expected to use Google Classroom creatively and expressively rather than in the real class. In this current era, technology became an essential part of our life, including in the educational world. Hopefully, the teacher could upgrade their ICT skill to facilitate the learning process. Besides, the teacher should find another tool to do online learning that supports students in cooperative learning by working in a group. The current study recommended further study. This study only took a part of the whole population of SMAN 08 Kota Bengkulu and produced the data above. Hopefully, the next study can continue this research on the other batch to get more varieties of data, and it can be a better suggestion for the e-learning world.

\section{References}

Arora A K, S. R. (2020). Impact of Pandemic Covid19 on the Teaching-Learning process. A Study of Higher Education Teachers. Prabandhan , 43.

Haase., E. \&. ( 2001). An analysis of potential target markets. Internet Research. Online business education in the twenty-first century, 246-260.

Golek, B. \&. (2004). Evaluating the Cost Effectiveness of Online and Face-to-Face Instruction. . Educational Technology \& Society , 167-175.

Nagele. (2017). teachers can make effective lessons that are student-centered.

Finch A. (2012). Attitude Change Through Learning. In: Seel N.M. (eds) Encyclopedia of the Sciences of Learning. Boston: Springer.

Nagele. (2017). Teachers can make effective lessons that are student- centered.

Finch A. (2012). Attitude Change Through Learning. In: Seel N.M. (eds) Encyclopedia of the Sciences of Learning. Boston: Springer.

Sukmawati. (2019). The Role of Google Classroom in ELT. International Journal for Educational and Vocational Studies, 144

Martínez-Monés, A., Reffay, C., Torío, J. H., \& Cristóbal, J. A. M. (2017, October). Learning Analytics with Google Classroom: Exploring the possibilities. In Proceedings of the 5th International Conference on Technological Ecosystems for Enhancing Multiculturality (p. 47). ACM. 
Fitriningtiyas, D. A. (2019). Google classroom: as a media of learning history.

Yates, D. (2017). Google Classroom Easiest Teacher's Guide to Master Google Classroom.

Finch A. (2012). Attitude Change Through Learning. In: Seel N.M. (eds) Encyclopedia of the Sciences of Learning. Boston: Springer.

Haase., E. \&. ( 2001). an analysis of potential target markets. Internet Research. Online business education in the twenty-first century, 246-260.

Golek, B. \&. (2004). Evaluating the Cost Effectiveness of Online and Face-to-Face Instruction. . Educational Technology \& Society , 167-175.

Roblyer, M. D. (2004). Integrating Educational Technology into Teaching, 3th edition, Upper Saddle River, . Pearson Education Inc , 190.

Ministry of Health, R. I. (2020). Indonesia, Ministry of Health of Republic Indonesia. jakarta, Indonesia: Guidelines for Preparedness against Coronavirus Disesase (Covid19).

Arora AK, S. R. (2020). Impact of Pandemic Covid19 on the Teaching-Learning process. A Study of Higher Education Teachers. Prabandhan , 43.

SCH Hoi, D. S. (2018). Online Learning. A Comprehensive Survey. Preprint ArXiv. , 1.

Parkinson, G. \&. (2011). Qualitative research. . In Online dictionary of the social sciences http://bitbucket.icaap.org/dict.pl.

Denzin, N. \&. (2005). Handbook of qualitative research. Thousand Oaks, C , 3.

Nassaji., H. (2015). Qualitative and descriptive research data type versus data analysis.

Flick, U2014 An introduction to qualitative researchLahore College for Women University

Neuman, W.Lawrence Social Research Methods:Qualitative and Quantitative Approaches.2003211

Ilker Etikan, Sulaiman Abubakar Musa, Rukayya Sunusi AlkassimSampling and Purposive SamplingJournal of Theoretical and Applied Statistics Journal of Theoretical and Applied Statistics. Comparison of Convenience20151-4

DiCicco-Bloom B. (2006). Crabtree BF. Med Educ . The qualitative research interview. , 1421.

JW., C. (2007). Qualitative Inquiry and Research Design: Choosing Among Five Approaches: International Student . California: Thousand Oaks, California: Sage Publications. 
Arvastson, G., \& Ehn, B.Etnografska observationer. Lund:2009

Moleong, L. J. (2000). Metodologi Penelitian Kualitatif. bandung: PT Remaja. Posdayakarya. Pedoman Umum Jalin Matra .

Schensul, L. a. (t.thn.). Analyzing and interpreting ethnographic data. Walnut Creek, CA: AltaMira Press. , 88.

LeCompte, M. D. (2010.). Designing \& Conducting Ethnographic Research: An Introduction. Lanham, Maryland: AltaMira Press.

Huberman, M. a. (1994). An Expanded Sourcebook: Qualitative Data Analysis. London: Sage Publications.

Dennis Howitt, D. C. (2000). First Steps In Research and Statistics. A Practical Workbook for Psychology Students. London: Routledge. .

Turner., P. T. (1978). Centre for Interaction Design. School of Computing, Edinburgh Napier University, Edinburgh .

Sharp (1998). critical appraisal of the role of triangulation in nursing research.

BrymanBryman. (1988). Quantity and Quality in Social Research. 45. 